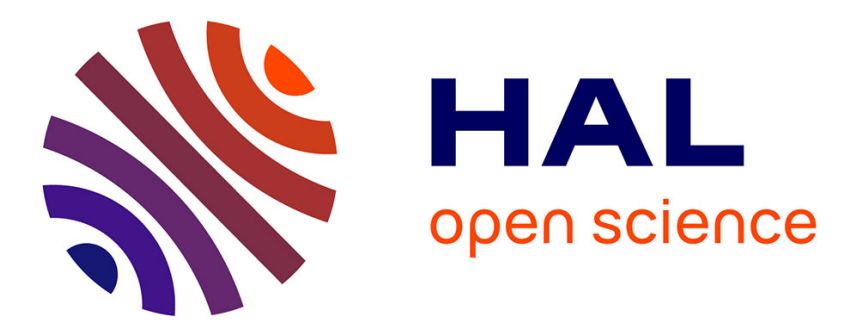

\title{
Aluminum-Hydride-Catalyzed Hydroboration of Carbon Dioxide
}

Cher-Chiek Chia, Yeow-Chuan Teo, Ning Cham, Samuel Ying-Fu Ho, Zhe-Hua Ng, Hui-Min Toh, Nicolas Mézailles, Cheuk-Wai So

\section{To cite this version:}

Cher-Chiek Chia, Yeow-Chuan Teo, Ning Cham, Samuel Ying-Fu Ho, Zhe-Hua Ng, et al.. AluminumHydride-Catalyzed Hydroboration of Carbon Dioxide. Inorganic Chemistry, 2021, 60 (7), pp.45694577. 10.1021/acs.inorgchem.0c03507 . hal-03405902

\section{HAL Id: hal-03405902 https://hal.science/hal-03405902}

Submitted on 27 Oct 2021

HAL is a multi-disciplinary open access archive for the deposit and dissemination of scientific research documents, whether they are published or not. The documents may come from teaching and research institutions in France or abroad, or from public or private research centers.
L'archive ouverte pluridisciplinaire HAL, est destinée au dépôt et à la diffusion de documents scientifiques de niveau recherche, publiés ou non, émanant des établissements d'enseignement et de recherche français ou étrangers, des laboratoires publics ou privés. 


\title{
Aluminum Hydride-Catalyzed Hydroboration of Carbon Dioxide
}

\author{
Cher-Chiek Chia, ${ }^{a}$ Yeow-Chuan Teo, ${ }^{a}$ Ning Cham, ${ }^{a}$ Samuel Ying-Fu Ho, ${ }^{a, b}$ Zhe-Hua Ng, ${ }^{a}$ Hui-Min \\ Toh, ${ }^{a}$ Nicolas Mézailles, ${ }^{b^{*}}$ Cheuk-Wai So ${ }^{a^{*}}$
}

${ }^{a}$ Division of Chemistry and Biological Chemistry, School of Physical and Mathematical Sciences, Nanyang Technological University, Singapore 637371. 'baboratoire Hétérochimie Fondamentale et Appliquée, CNRS, Université Paul Sabatier, 31062 Toulouse, France.

\begin{abstract}
This study describes the first use of a bis(phosphoranyl)methanido aluminum hydride, $\left[\mathrm{ClC}\left(\mathrm{PPh}_{2} \mathrm{NMes}_{2} \mathrm{AlH}_{2}\right]\left(\mathbf{2}\right.\right.$, Mes $\left.=\mathrm{Me}_{3} \mathrm{C}_{6} \mathrm{H}_{2}\right)$ for the catalytic hydroboration of $\mathrm{CO}_{2}$. Complex 2 was synthesized by the reaction of a lithium carbenoid $\left[\mathrm{Li}(\mathrm{Cl}) \mathrm{C}\left(\mathrm{PPh}_{2} \mathrm{NMes}\right)_{2}\right]$ with two equivalents of $\mathrm{AlH}_{3} \cdot \mathrm{NEtMe}_{2}$ in toluene at $-78^{\circ} \mathrm{C} .10 \mathrm{~mol} \%$ of 2 was able to catalyze the reduction of $\mathrm{CO}_{2}$ with HBpin in $\mathrm{C}_{6} \mathrm{D}_{6}$ at $110{ }^{\circ} \mathrm{C}$ for 2 days to afford a mixture of methoxyborane [MeOBpin] (3a; yield: $78 \%$, TOF: $0.16 \mathrm{~h}^{-1}$ ) and bis(boryl)oxide [pinBOBpin] (3b). When more potent $\left[\mathrm{BH}_{3} \cdot \mathrm{SMe}_{2}\right]$ was used instead of HBpin, the catalytic reaction was extremely pure, resulting in the formation of trimethyl borate $\left[\mathrm{B}(\mathrm{OMe})_{3}\right]$ (3e) [catalytic loading: $1 \mathrm{~mol} \%$ (10 mol \%); reaction time: $60 \mathrm{~min}(5 \mathrm{~min})$; yield: $97.6 \%$ (>99 \%); TOF: $292.8 \mathrm{~h}^{-1}\left(356.4 \mathrm{~h}^{-1}\right)$ ] and $\mathrm{B}_{2} \mathrm{O}_{3}(3 \mathrm{f})$. Mechanistic studies show that the Al-H bond in complex 2 activated $\mathrm{CO}_{2}$ to form $\left[\mathrm{ClC}\left(\mathrm{PPh}_{2} \mathrm{NMes}\right)_{2} \mathrm{Al}(\mathrm{H})\{\mathrm{OC}(\mathrm{O}) \mathrm{H}\}\right](4)$, which was subsequently reacted with $\mathrm{BH}_{3} \cdot \mathrm{SMe}_{2}$ to form $3 \mathbf{e}$ and 3 f, along with the regeneration of complex 2. Complex 2 also shows good catalytic activity towards hydroboration of carbonyl, nitrile and alkyne derivatives.
\end{abstract}

Introduction

Main-group elements are considered as sustainable alternatives to precious transition-metal species in chemical catalysis due to their high abundancy and relatively low toxicity. ${ }^{1}$ In particular, aluminum is the most abundant main-group element and its Lewis acidic compounds have shown to catalyze a wide range of classic organic reactions, such as the Meerwein-Ponndorf-Verley reduction of carbonyls, ${ }^{2}$ Friedel-Crafts acylation of aromatics ${ }^{3}$ and the ring-opening polymerization of lactams. ${ }^{4}$ However, aluminum does not possess donor and acceptor valence orbitals with small energy gaps, which classically prevents aluminum compounds to mimic transitionmetal complexes in catalysis. In the past few years, this limitation has been overcome by designing novel aluminum hydride compounds with highly polarized Al-H bonds. The hydridic $\mathrm{H}$ atoms are able to display reactivity similar to transition metal hydride complexes. ${ }^{5}$ For example, Berben et al. showed that bis(imino)pyridine complex of aluminum catalyzed the dehydrogenative coupling of benzylamine, ${ }^{6}$ dehydrogenation of formic acid, ${ }^{7}$ and electrocatalytic production of hydrogen via a metal-ligand cooperative mechanism. ${ }^{8}$ Roesky et al. illustrated that the $\beta$-diketiminato aluminum hydride complexes mediated the catalytic hydroboration of carbonyl compounds and alkynes. ${ }^{9,10}$ Thomas and Cowley et al. reported that commercially available aluminum hydrides such as DIBAL-H and $\mathrm{LiAlH}_{4}$ catalyzed the hydroboration of alkenes, alkynes, and nitriles via $\sigma$-bond metathesis. ${ }^{11,12}$ Research groups of Harder and Mulvey reported that lithium aluminates catalyzed hydrophosphination of alkynes and hydrogenation of imines through a $\mathrm{Li}-\mathrm{Al}$ cooperation mechanism. ${ }^{13,14}$ Nikonov et al. also demonstrated that the $\beta$-diketiminato aluminum hydride complex catalyzed the hydrosilylation of alkenes via the activation of silane by the Lewis acidic aluminum center in the first step of the catalysis. ${ }^{15}$ Rueping et al. reported the first asymmetric hydroboration of ketones using aluminum complexes bearing chiral biphenol-type ligands. ${ }^{16}$ These results serve as evidence that tailor-made aluminum hydride complexes exhibit transition-metal like reactivity in mediating catalytic reduction of unsaturated polar bonds $(\mathrm{C}=\mathrm{O}$, $\mathrm{C}=\mathrm{N}$ ) and $\mathrm{C}-\mathrm{C}$ multiple bonds. Despite these pertinent recent developments, the implementation of aluminum hydride complexes for catalytic $\mathrm{CO}_{2}$ transformation into value-added chemicals has not been reported. ${ }^{17}$ In fact, Aldridge et al. showed that $\beta$-diketiminato aluminum hydride complexes are not efficient catalysts for the hydroboration of $\mathrm{CO}_{2}$ with boranes because of unfavorable kinetics of the $\sigma$-bond metathesis mechanism. ${ }^{18}$ Inoue et al. reported that $\mathrm{N}$-heterocyclic imido aluminum hydride complexes promoted $\mathrm{CO}_{2}$ reduction through a nonaluminum-containing intermediate to form ill-defined product mixtures. ${ }^{19}$

Recently, a series of bis(phosphoranyl)methanediide and methanide complexes of main-group elements have been shown, whereby the ylidic PN bonds ( $\mathrm{P}=\mathrm{N} \leftrightarrow \mathrm{P}^{+}-\mathrm{N}^{-}$; Figure 1 ) of the ligands promote strong electron transfer from the $\mathrm{N}$ atoms to main-group elements. ${ }^{20}$ In particular, we have shown that the boron derivatives of bis(phosphoranyl)methanediide and methanide, $\left[\mathrm{H}_{5} \mathrm{~B}_{2}-\mathrm{C}\left(\mathrm{PPh}_{2} \mathrm{~S}\right)_{2} \mathrm{Li}\left(\mathrm{OEt}_{2}\right)\right]{ }^{21}$ and $\left[\mathrm{ClC}\left(\mathrm{PPh}_{2} \mathrm{NMes}\right)_{2} \mathrm{BH}_{2}\right]^{22}$ were among the most efficient catalysts for $\mathrm{CO}_{2}$ reduction to methanol derivatives. We 
anticipated that such electronic properties could also enhance the hydridic character of an $\mathrm{Al}-\mathrm{H}$ bond, resulting in the kinetically and thermodynamically favorable addition to $\mathrm{CO}_{2}$. Herein, we report the synthesis of a bis(phosphoranyl)methanido aluminum hydride and its use in the catalytic hydroboration of $\mathrm{CO}_{2}$ coupled with DFT calculations that rationalize our experimental findings. We also report that this complex is an efficient catalyst for the hydroboration of a wide variety of substrates, such as aldehydes, ketones, nitriles and alkynes.

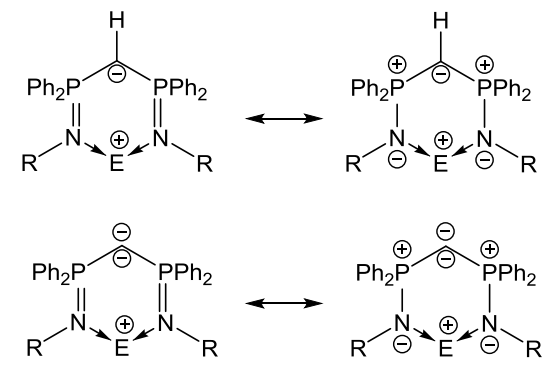

Figure 1. Ylidic structure of bis(phosphoranyl)methanediide and methanide complexes of main-group elements (E)

\section{Results and Discussion}

Our starting point was the lithium carbenoid $\left[\mathrm{Li}(\mathrm{Cl}) \mathrm{C}\left(\mathrm{PPh}_{2} \mathrm{NMes}\right)_{2}\right]\left(\mathbf{1}\right.$, Mes $\left.=\mathrm{C}_{6} \mathrm{H}_{2} \mathrm{Me}_{3}\right)$ species which we reported in $2015 .{ }^{22}$ Upon treatment with two equivalents of $\mathrm{AlH}_{3} \cdot \mathrm{NEtMe}_{2}$ in toluene at $-78{ }^{\circ} \mathrm{C}$ followed by warming to room temperature and stirring for 1 hour (Scheme 1), a white suspension was observed. After filtering the white precipitate, which was identified as $\mathrm{LiAlH}_{4}$, $\left[\mathrm{ClC}\left(\mathrm{PPh}_{2} \mathrm{NMes}_{2} \mathrm{AlH}_{2}\right]\right.$ (2) was obtained as a colorless crystalline solid (92\% yield) in the concentrated filtrate. The results show that $\mathrm{AlH}_{3} \cdot \mathrm{NEtMe}_{2}$ undergoes a disproportionation reaction to form " $\mathrm{AlH}_{2}{ }^{+}$", stabilized by the carbenoid backbone, and an $\mathrm{AlH}_{4}{ }^{-}$species in the presence of compound 1. Complex 2 was analyzed and characterized by NMR spectroscopy and X-ray crystallography. The ${ }^{1} \mathrm{H}$ NMR spectrum shows a set of signals for the ligand backbone while featuring a broad signal at $5.0 \mathrm{ppm}$ with an integration of $2 \mathrm{H}$ representing the $\mathrm{AlH}_{2}^{+}$moiety. The ${ }^{31} \mathrm{P}$ NMR spectroscopy shows a new singlet at 39.0 ppm, more than $10 \mathrm{ppm}$ downfield from $1(\delta 27.2 \mathrm{ppm}){ }^{22} \mathrm{X}$-ray crystal structure of 2 (Figure 2) features a six-membered CPNAINP ring in a half chair conformation due to the presence of an $\mathrm{AlH}_{2}{ }^{+}$moiety (Al-N: 1.886(3), 1.900(3) Å). The $\mathrm{C}_{1}$ atom is planar, which agrees with the absence of a $\mathrm{CH}$ bond reflected in the NMR data. The P-N bond lengths in 2 are elongated (1.623(3), 1.625(3) $\AA$ ) in comparison with those in $1(1.596(3), 1.593(2) \AA),{ }^{22}$ which indicates that the negative charge on the $\mathrm{C}_{1}$ atom in 2 is more delocalized into the P-N $\sigma^{*}$ orbitals by negative hyperconjugation. Complex $\mathbf{2}$ is air- and moisturesensitive, as well as being soluble and stable in non-polar solvents like benzene and toluene up to $120{ }^{\circ} \mathrm{C}$. Decomposition into the protonated ligand $\left[\mathrm{Cl}(\mathrm{H}) \mathrm{C}\left(\mathrm{PPh}_{2} \mathrm{NMes}\right)_{2}\right]$ in hot toluene was not observed.

Next, the catalytic ability of the bis(phosphoranyl)methanido aluminum hydride complex 2 towards the hydroboration of $\mathrm{CO}_{2}$ with boranes was then examined. To begin with, we verified that there was no reaction between $\mathrm{CO}_{2}$ and boranes (HBpin, $\mathrm{BH}_{3} \cdot \mathrm{SMe}_{2}$ and HBcat) in $\mathrm{C}_{6} \mathrm{D}_{6}$ at $110{ }^{\circ} \mathrm{C}$. In addition, there was no reaction between complex 2 and HBpin at $110{ }^{\circ} \mathrm{C}$ for 48 h. ${ }^{29}$ In the presence of 2 (10 $\left.\mathrm{mol} \%\right)$, the reduction of $\mathrm{CO}_{2}$ with HBpin in $\mathrm{C}_{6} \mathrm{D}_{6}$ at $110{ }^{\circ} \mathrm{C}$ afforded a mixture of methoxyborane [MeOBpin] (3a, Scheme 2) $(55.8 \%$ in 24 h; $78 \%$ in $48 \mathrm{~h}$, TOF: $0.16 \mathrm{~h}^{-1}$ ) and bis(boryl)oxide [pinBOBpin] (3b). The catalytic activity in terms of TOF is in the range of other main-group metal-catalyzed $\mathrm{CO}_{2}$ hydroboration with pinacolborane (HBpin) $(\mathrm{TOF}=0.07-$ $\left.14.5 \mathrm{~h}^{-1}\right){ }^{23} \mathrm{~A}$ similar reduction of $\mathrm{CO}_{2}$ with catecholborane (HBcat) using 2 as a catalyst proceeded with less efficiency $(24 \mathrm{~h}, 28.8 \%$ conversion) to afford a mixture of methoxyborane [catBOMe] (3c) and bis(boryl)oxide $\left[(\text { catB })_{2} \mathrm{O}\right](3 \mathrm{~d})$. In the catalysis, most of HBcat was unreacted, while a mixture of $\mathrm{B}_{2}(\mathrm{cat})_{3,}{ }^{11} \mathrm{~B}$ NMR: $\left.22.5 \mathrm{ppm}\right)$ and four-coordinate borane compounds ("$B$ NMR: -14.5 ppm) was observed. This suggests that intermediates in the catalysis could react with $\mathrm{HBcat}$ to form $\mathrm{B}_{2}(\mathrm{cat})_{3}$ and catalytically inactive complexes, leading to low conversion of the catalysis.

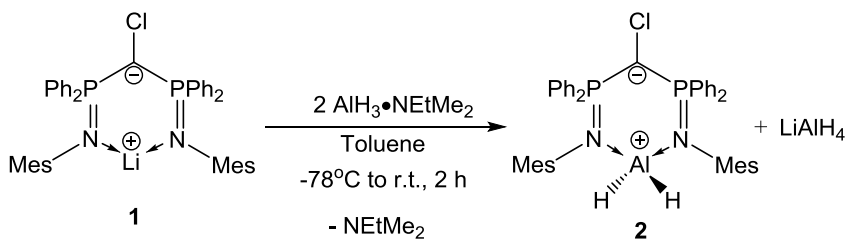

Scheme 1. Synthesis of the bis(phosphoranyl)methanido aluminum hydride 2

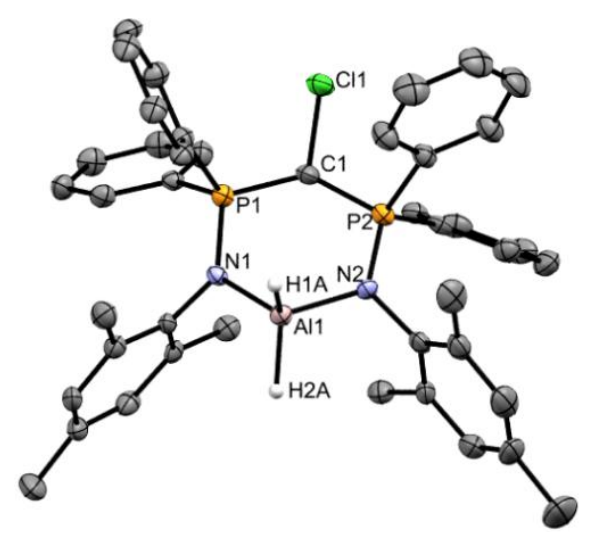

Figure 2. X-ray crystal structure of $\mathbf{2}$ with thermal ellipsoids at $50 \%$ probability. All $\mathrm{H}$ atoms except on the All atom are omitted for clarity. Selected bond lengths $(\AA \AA)$ and angles (deg): Cl1-C1 1.785(3), C1-P2 1.725(4), P2-N2 1.623(3), N2-Al1 1.886(3), Al1-N1 1.90o(3), N1-P1 1.625(3), P1-C1 1.719(4), P2-C1P1 133.3(2), N2-Al1-N1 103.6(1).

When more potent and $\mathrm{NaBH}_{4}-\mathrm{free}^{24}\left[\mathrm{BH}_{3} \cdot \mathrm{SMe}_{2}\right]$ was used instead of HBpin, the catalytic reaction was much more efficient (1 mol \% of 2), forming trimethyl borate $\left[\mathrm{B}(\mathrm{OMe})_{3}\right]$ (3e) in only $1 \mathrm{~h}$ (Yield: $97.6 \%$, TOF: $292.8 \mathrm{~h}^{-1}$, Scheme 2) together with white precipitates. Hydrolysis of the latter in $\mathrm{D}_{2} \mathrm{O}$ quantitatively formed boric acid (by ${ }^{11} \mathrm{~B}$ NMR) which is indicative that the white precipitate formed during the catalysis is $\mathrm{B}_{2} \mathrm{O}_{3}$. When the 
amount of complex 2 was increased to $10 \mathrm{~mol} \%$, the catalytic activity increased significantly $\left(5 \mathrm{~min}, 110{ }^{\circ} \mathrm{C}\right.$, Yield: $>99 \%$, TOF: $356.4 \mathrm{~h}^{-1}$ ). Complex $\mathbf{2}$ is one of the very few main-group element compounds that can catalyze the reduction of $\mathrm{CO}_{2}$ with $\mathrm{BH}_{3}$, including the ambiphilic phosphine-borane compound $\left[1-\mathrm{B}(\mathrm{OR})_{2}-2-\mathrm{PR}_{2}-\mathrm{C}_{6} \mathrm{H}_{4}\right]$ (TOF: $43-257 \mathrm{~h}^{-1} ; \mathrm{R}^{\prime}=\mathrm{Ph}, i \mathrm{Pr} ;(\mathrm{OR})_{2}=(\mathrm{OMe})_{2}$, catechol, pinacol), ${ }^{25}$ bis(thiophosphinoyl)methanide-supported lithium borohydride $\left[\mathrm{H}_{5} \mathrm{~B}_{2}-\mathrm{C}\left(\mathrm{PPh}_{2} \mathrm{~S}\right)_{2} \mathrm{Li}\left(\mathrm{OEt}_{2}\right)\right]$ (TOF: 150 $\left.\mathrm{h}^{-1}\right){ }^{21}$ bis(iminophosphoranyl)methanido boron hydride $\left[\mathrm{ClC}\left(\mathrm{PPh}_{2} \mathrm{NMes}_{2} \mathrm{BH}_{2}\right]\right.$ (TOF: $\left.157 \mathrm{~h}^{-1}\right){ }^{22}$ ring expansion product arising from phosphine-derived carbenes with $9^{-}$ borabicyclo[3.3.1]nonane $(9-\mathrm{BBN})^{26}$ and NHCsilyliumylidene complex $\left[\left(\mathrm{I}_{\mathrm{Me}}\right)_{2} \mathrm{SiH}\right] \mathrm{I}$ (TOF: $19.8 \mathrm{~h}^{-1}, \mathrm{I}_{\mathrm{Me}}=$ $\left.: \mathrm{C}\{\mathrm{N}(\mathrm{Me}) \mathrm{C}(\mathrm{Me})\}_{2}\right){ }^{27}$ It is noteworthy that the catalytic activity of complex 2 is more efficient than these examples in terms of both reaction time and TOF.

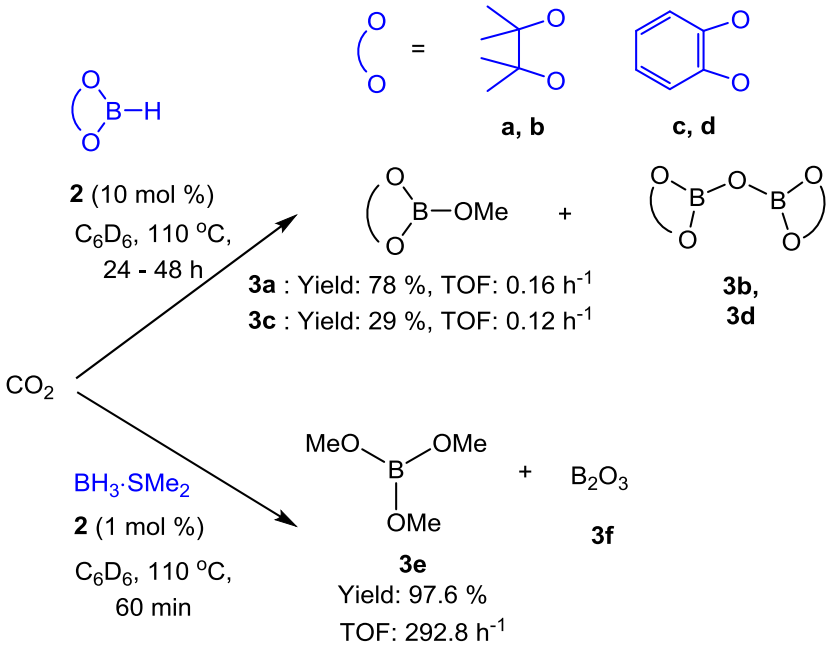

Scheme 2. 2-catalyzed hydroboration of $\mathrm{CO}_{2}$. Yields were calculated based on conversion of $\mathrm{H}$.

The catalytic mechanism was studied by performing stoichiometric step-wise reactions with the aim of isolating reactive intermediates. Complex 2 was reacted with $\mathrm{CO}_{2}$ in toluene at room temperature for $15 \mathrm{~min}$ (Scheme 3), whereby complex 2 was fully consumed. The ${ }^{31} \mathrm{P}$ NMR spectrum of the reaction mixture showed a single new signal at $40.5 \mathrm{ppm}$, while the ${ }^{1} \mathrm{H}$ NMR spectrum showed a new singlet at $8.5 \mathrm{ppm}(1 \mathrm{H})$ suggesting the formation of a formate moiety coupled with a set of signals representative of the bis(iminophosphoranyl)methanido ligand. The spectroscopic data indicates that $\mathrm{CO}_{2}$ inserts into one $\mathrm{Al}-\mathrm{H}$ bond in complex 2 to form $\left[\mathrm{ClC}\left(\mathrm{PPh}_{2} \mathrm{NMes}\right)_{2} \mathrm{Al}(\mathrm{H})\{\mathrm{OC}(\mathrm{O}) \mathrm{H}\}\right]$ (4). It was isolated as a white precipitate by simply removing volatiles of the reaction mixture in vacuo. Complex 4 is stable in the solid state, but slowly decomposes in $\mathrm{C}_{6} \mathrm{D}_{6}$, toluene and $\mathrm{CH}_{2} \mathrm{Cl}_{2}$. Efforts were made to crystallize this compound in $\mathrm{CH}_{2} \mathrm{Cl}_{2}$, which was unsuccessful due to its slow evolution in solution. However, a single new species formed after a week in attempts to crystallize 4, indicative by the appearance of a new signal at $42.5 \mathrm{ppm}$ in the ${ }^{31} \mathrm{P}$ NMR spectrum. The ${ }^{1} \mathrm{H}$ NMR spectrum showed a singlet at $8.24 \mathrm{ppm}$ with an integration of 4 indicating the for- mation of two $\mathrm{OCH}_{2} \mathrm{O}$ moieties. In addition, the ${ }^{1} \mathrm{H}$ NMR spectrum showed a set of signals for the bis(iminophosphoranyl)methanido ligand. Colorless crystals were obtained from the initial $\mathrm{CH}_{2} \mathrm{Cl}_{2}$ solution of 4 , crystallized at o ${ }^{\circ} \mathrm{C}$ for one week. The X-ray crystallographic analysis proved the formation of the acetal derivative $\left[\mathrm{LAl}\left(\mathrm{OCH}_{2} \mathrm{O}\right)_{2} \mathrm{AlL}\right]\left(4-\mathrm{D}, \mathrm{L}=\mathrm{ClC}\left(\mathrm{PPh}_{2} \mathrm{NMes}_{2}\right)\right.$. Thus, in the absence of any additional substrate, the second Al-H is sufficiently hydridic to reduce the formate moiety to an acetal moiety. Complex 4-D is stable in solution (toluene, $\mathrm{CH}_{2} \mathrm{Cl}_{2}$ ) and in solid state. The X-ray crystal structure of complex 4 -D comprises of an $\mathrm{Al}\left(\mathrm{OCH}_{2} \mathrm{O}\right)_{2} \mathrm{Al}$ eight membered ring (Figure 3 ). The ring structure (Al-O: $1.731(4), 1.710(8) \AA$ ) is comparable with the one supported by $\beta$-diketiminate ligand $\left[\mathrm{RAl}\left(\mathrm{OCH}_{2} \mathrm{O}\right)_{2} \mathrm{AlR}\right]$ (Al-O: 1.7123(11), 1.7239(11) Å; R = HC\{C(Me)NDipp $\}_{2}$, Dipp = 2,6$\left.i \mathrm{Pr}_{2} \mathrm{C}_{6} \mathrm{H}_{3}\right)$, which was isolated from the reaction of the germanium(II) formate $[\mathrm{RGeOC}(\mathrm{O}) \mathrm{H}]$ and aluminum hydride $\left[\mathrm{RAlH}_{2}\right]^{28}$

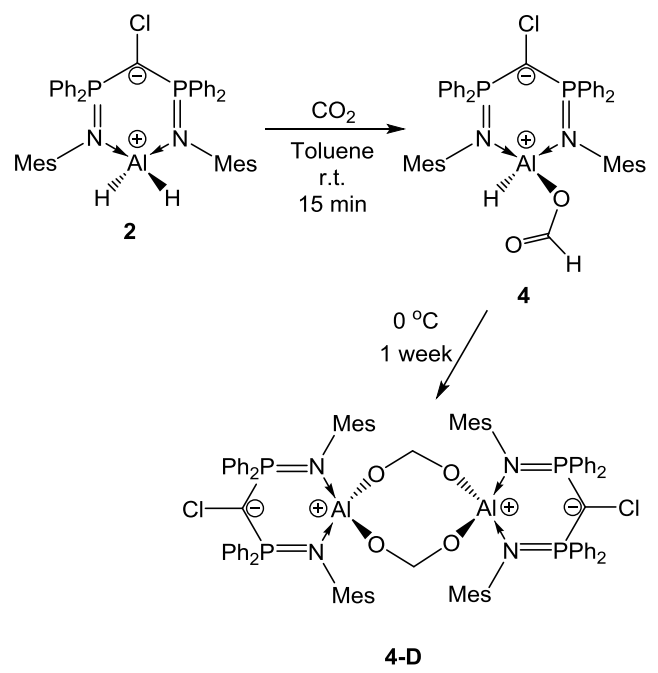

Scheme 3. Formation of complex 4-D

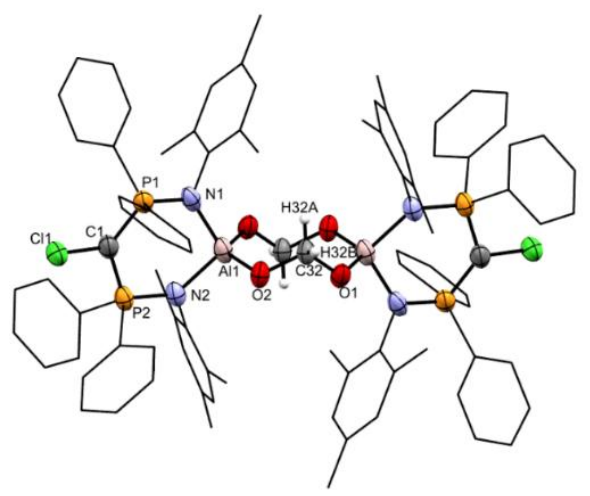

Figure 3. X-ray crystal structure of 4 -D with thermal ellipsoids at the $50 \%$ probability level. Selected hydrogen atoms are elided for clarity. Selected bond lengths $(\AA)$ and angles (deg): Cl1-C1 1.797(5), C1-P1 1.747(6), C1-P2 1.704(6), P2-N2 $1.632(4), \mathrm{P}_{1}-\mathrm{N}_{1} 1.624(4), \mathrm{N}_{1}-\mathrm{Al}_{1} 1.881(5), \mathrm{N}_{2}-\mathrm{Al}_{1}$ 1.891(4), Al1$\mathrm{O}_{2}$ 1.731(4), Al1-O1 1.710(8), O1-C32 1.392(11), O2-C32 1.476(8), N1-Al1-N2 104.64(19), O1A-Al1-O2 109.2(5), N1-Al1-O1A $119.5(4), \mathrm{N}_{2}-\mathrm{Al}_{1}-\mathrm{O}_{2}$ 108.80(19), $\mathrm{Al}_{1}-\mathrm{O}_{2}-\mathrm{C}_{32}$ 116.6(4), O2-C32O1 111.2(8). 


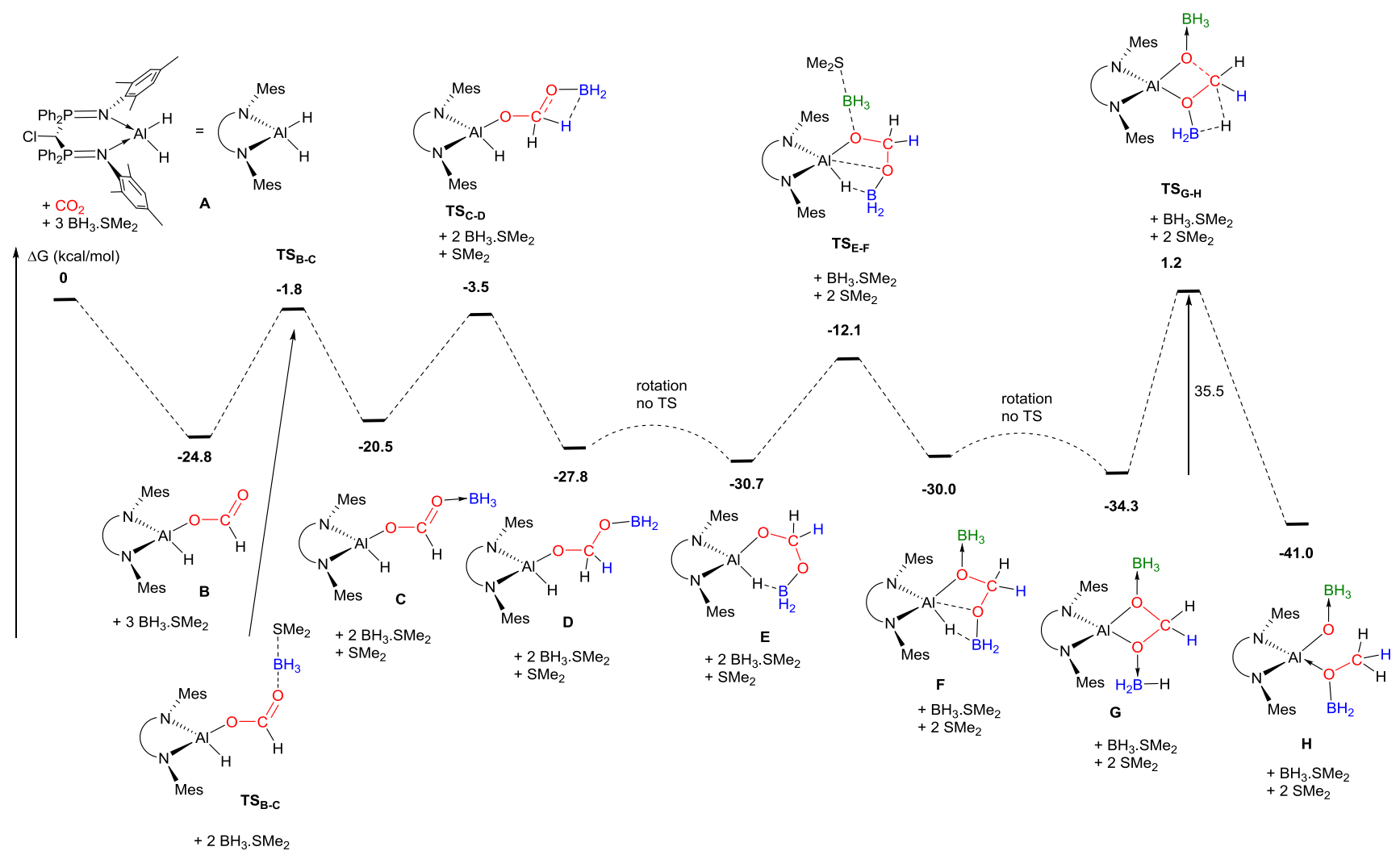

Scheme 4. DFT studies of catalytic $\mathrm{CO}_{2}$ hydroboration with $\mathrm{BH}_{3} \cdot \mathrm{SMe}_{2}$ from Complex $\mathbf{A}$ to $\mathbf{H}$, showing the three $\mathrm{C}-\mathrm{H}$ bond formations from $\mathrm{CO}_{2} . \Delta \mathrm{G}$ in $\mathrm{kcal} / \mathrm{mol}$, calculated at $298 \mathrm{~K}$.

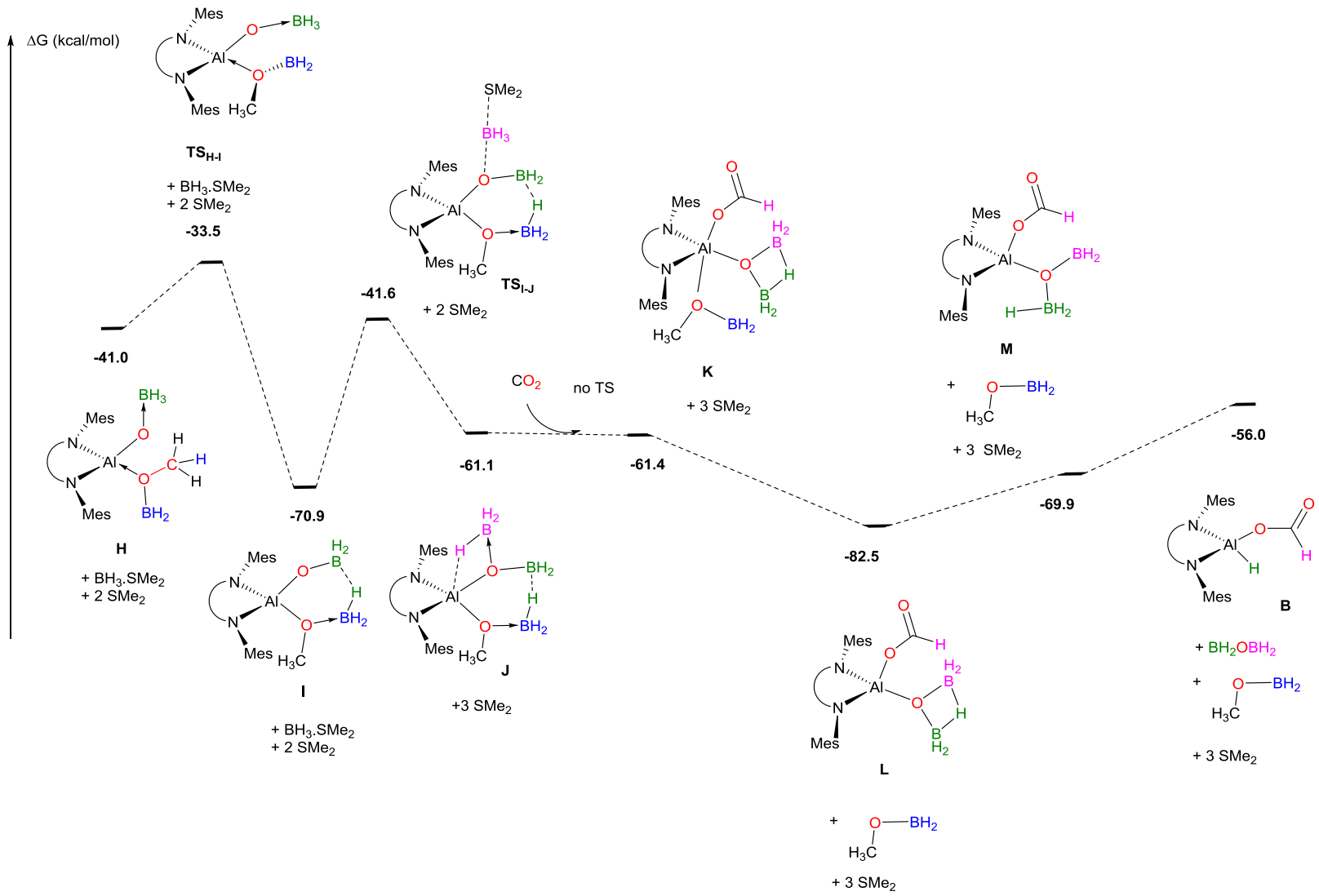

Scheme 5. DFT studies of catalytic $\mathrm{CO}_{2}$ hydroboration with $\mathrm{BH}_{3} \cdot \mathrm{SMe}_{2}$ from $\mathbf{H}$ to the formation of $3 \mathbf{e}$ and regeneration of B. $\Delta \mathrm{G}$ in $\mathrm{kcal} / \mathrm{mol}$, calculated at $298 \mathrm{~K}$. 
To prove that complex 4 is an intermediate in the catalysis, $10 \mathrm{~mol} \%$ of 4 was used to catalyze the reaction of $\mathrm{CO}_{2}$ with HBpin in $\mathrm{C}_{6} \mathrm{D}_{6}$ at $110{ }^{\circ} \mathrm{C}$ for $48 \mathrm{~h}$ to afford a mixture of methoxyborane $3 a$ (Yield: $78 \%$ ) and bis(boryl)oxide $\mathbf{3 b}$. Similarly, 4-catalyzed hydroboration of $\mathrm{CO}_{2}$ with $\mathrm{BH}_{3} \cdot \mathrm{SMe}_{2}$ in $\mathrm{C}_{6} \mathrm{D}_{6}$ at $110{ }^{\circ} \mathrm{C}$ formed $\left[\mathrm{B}(\mathrm{OMe})_{3}\right]$ (3e, Yield: $98 \%$ ) in 60 mins. The yields of the products are comparable with those in the catalytic $\mathrm{CO}_{2}$ hydroboration using $\mathbf{2}$ as a catalyst. In particular, complex $\mathbf{2}$ was regenerated after these catalytic runs. On the other hand, $10 \mathrm{~mol} \%$ of complex 4 -D was unable to catalyze the hydroboration of $\mathrm{CO}_{2}$ with $\mathrm{HBpin}$ or $\mathrm{BH}_{3} \cdot \mathrm{SMe}_{2}$ in $\mathrm{C}_{6} \mathrm{D}_{6}$ at $110^{\circ} \mathrm{C}$. In summary, these results show that complex 2 is an active catalyst and complex 4 is an intermediate in the catalytic reduction of $\mathrm{CO}_{2}$, while 4 -D is an off-cycle product.

Moreover, complex 4 was reacted with 3 equivalents of $\mathrm{BH}_{3} \cdot \mathrm{SMe}_{2}$ in $\mathrm{C}_{6} \mathrm{D}_{6}$ to form a mixture of bis(iminophosphoranyl)methanido compounds, confirmed by ${ }^{31} \mathrm{P}$ NMR spectroscopy (7 signals: 41.1 - 42.5 $\mathrm{ppm})$. The reaction mixture was then heated at $110{ }^{\circ} \mathrm{C}$ overnight. ${ }^{31} \mathrm{P}$ NMR spectroscopy showed that complex 2 was regenerated, along with the formation of $\mathrm{B}(\mathrm{OMe})_{3}$ represented by ${ }^{11} \mathrm{~B}$ NMR spectroscopy. This indicates that the 2-catalyzed $\mathrm{CO}_{2}$ hydroboration with $\mathrm{BH}_{3} \cdot \mathrm{SMe}_{2}$ proceeds via several intermediates and complex 2 is the active catalyst in the mechanism. To further support our claim that the reaction proceeds via several intermediates, HRMS was performed and we were able to detect the presence of such intermediates (Scheme 4 and 5; C-E: HRMS (ESI): $m / z$ calcd for $\mathrm{C}_{44} \mathrm{H}_{48} \mathrm{BN}_{2} \mathrm{O}_{2} \mathrm{AlP}_{2} \mathrm{Cl}: 771.2788$ $[(\mathrm{M}+\mathrm{H})]^{+}$; found: 771.2774. F-I: HRMS (ESI): $\mathrm{m} / \mathrm{z}$ calcd for $\mathrm{C}_{44} \mathrm{H}_{51} \mathrm{~B}_{2} \mathrm{~N}_{2} \mathrm{O}_{2} \mathrm{AlP}_{2} \mathrm{Cl}$ : $785 \cdot 3116[(\mathrm{M}+\mathrm{H})]^{+}$; found: 785.3167. J: HRMS (ESI): $\mathrm{m} / \mathrm{z}$ calcd for $\mathrm{C}_{44} \mathrm{H}_{54} \mathrm{~B}_{3} \mathrm{~N}_{2} \mathrm{O}_{2} \mathrm{AlP}_{2} \mathrm{Cl}: 799.3444[(\mathrm{M}+\mathrm{H})]^{+}$; found: 799.3474. K: HRMS (ESI): $\mathrm{m} / \mathrm{z}$ calcd for $\mathrm{C}_{44} \mathrm{H}_{49} \mathrm{~B}_{2} \mathrm{~N}_{2} \mathrm{O}_{3} \mathrm{AlP}_{2} \mathrm{Cl}: 799.2908[(\mathrm{M}+\mathrm{H})]^{+}$; found: 799.2938. L-M: HRMS (ESI): $\mathrm{m} / \mathrm{z}$ calcd for $\mathrm{C}_{44} \mathrm{H}_{49} \mathrm{~B}_{2} \mathrm{~N}_{2} \mathrm{O}_{3} \mathrm{AlP}_{2} \mathrm{Cl}: 771.2908[(\mathrm{M}+\mathrm{H})]^{+}$; found: 771.2978.).

On the basis of these experimental studies, a catalytic cycle for the hydroboration of $\mathrm{CO}_{2}$ with $\mathrm{BH}_{3} \cdot \mathrm{SMe}_{2}$ is proposed (Scheme 4 and 5) and studied by DFT calculations (see the Supporting Information for details). Complex $\mathbf{B}$ results from insertion of $\mathrm{CO}_{2}$ into an $\mathrm{Al}-\mathrm{H}$ bond of complex A (model of compound 2 ) in a strongly exergonic step $(\Delta G=-24.8 \mathrm{kcal} / \mathrm{mol})$. A transition state for this process was not found, despite several attempts. $\mathrm{BH}_{3} \cdot \mathrm{SMe}_{2}$ then coordinates with the $\mathrm{C}=\mathrm{O}$ double bond through $\mathbf{T S}_{\mathrm{B}-\mathrm{C}}(\Delta \mathrm{G}=-1.8 \mathrm{kcal} / \mathrm{mol})$ to form compound $\mathbf{C}$ $(\Delta \mathrm{G}=-20.5 \mathrm{kcal} / \mathrm{mol})$. The transition state for $\mathrm{SMe}_{2}$ substitution by the $\mathrm{CO}$ moiety at $\mathrm{BH}_{3}$ is accessible, requiring $23.0 \mathrm{kcal} / \mathrm{mol}$. Subsequently, the $\mathrm{B}-\mathrm{H}$ bond in compound C adds to the $>\mathrm{C}=\mathrm{O}$ bond via TS $_{\mathrm{C}-\mathrm{D}}(\Delta \mathrm{G}=-3.5 \mathrm{kcal} / \mathrm{mol})$ to form complex $\mathbf{D}(\Delta \mathrm{G}=-27.8 \mathrm{kcal} / \mathrm{mol})$. At this point, it is obvious that the first two $\mathrm{C}-\mathrm{H}$ bond formations are kinetically facile processes. The acetal group in compound $\mathbf{D}$ then undergoes rotation around the $\mathrm{C}-\mathrm{O}$ bond to form compound $\mathbf{E}(\Delta \mathrm{G}=-30.7 \mathrm{kcal} / \mathrm{mol})$, concurrently allowing the borane to interact with the aluminum hydride. A second $\mathrm{BH}_{3} \cdot \mathrm{SMe}_{2}$ has then to be added to allow for the third $\mathrm{C}-\mathrm{H}$ bond to be formed. It coordinates to the oxygen atom of the acetal group in compound $\mathbf{E}$, to result in complex $\mathbf{F}$, which is almost iso-energetic $(\Delta \mathrm{G}=-30.0$

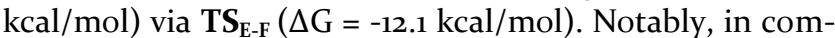
plex $\mathbf{F}$, the oxygen atom and $\mathrm{BH}_{2}$ moieties are adequately positioned to favor $\mathrm{Al}-\mathrm{O}$ bond and $\mathrm{BH}$ bond formations leading to complex $\mathbf{G}(\Delta \mathrm{G}=-34.3 \mathrm{kcal} / \mathrm{mol})$, in a facile process (without TS). Complex $\mathbf{G}$ is a symmetrical complex featuring two $\mathrm{Al}-\mathrm{O}$ bonds and two $\mathrm{O}-\mathrm{BH}_{3}$ moieties. Subsequently, the $\mathrm{B}-\mathrm{H}$ bond is added to the acetal group via $\mathbf{T S}_{\mathrm{G}-\mathrm{H}}(\Delta \mathrm{G}=-5.3 \mathrm{kcal} / \mathrm{mol})$ resulting in the cleavage of the $\mathrm{O}-\mathrm{C}$ bond and the formation of $\mathrm{MeOBH}_{2}$ coordinated to the $\mathrm{Al}$ center in complex $\mathbf{H}(\Delta \mathrm{G}=-41.0 \mathrm{kcal} / \mathrm{mol})$. The formation of the third $\mathrm{C}-\mathrm{H}$ bond is the rate determining step of the whole process. The computed barrier of 35.5 $\mathrm{kcal} / \mathrm{mol}$ is rather high, but consistent with a reaction requiring $110{ }^{\circ} \mathrm{C}$ to occur. At this point, the " $\mathrm{CH}_{3} \mathrm{O}$ " moiety has been generated from $\mathrm{CO}_{2}$, and the second part of the process is dedicated to its elimination as " $\mathrm{CH}_{3} \mathrm{OBH}_{2}$ " from the $\mathrm{Al}$ center and reformation of $\mathrm{Al}-\mathrm{H}$ moieties to initiate a second cycle as depicted in Scheme 5. A facile rotation around the $\mathrm{Al}-\mathrm{O}$ axes of the $\mathrm{MeOBH}_{2}$ and $\mathrm{OBH}_{3}$ moieties leads to a very strong stabilization (complex $\mathbf{I}, \Delta \mathrm{G}=-70.9$ $\mathrm{kcal} / \mathrm{mol}$ ). The associated $\mathrm{TS}_{\mathrm{H}-\mathrm{I}}$ is found at $\Delta \mathrm{G}=-33.5$ $\mathrm{kcal} / \mathrm{mol}$, just $7.5 \mathrm{kcal} / \mathrm{mol}$ higher than complex $\mathbf{H}$. In complex I, the $\mathrm{BH}_{3}$ moiety forms an unsymmetrical 3c-2e interaction with the $\mathrm{BH}_{2}$ group of $\mathrm{MeOBH}_{2}$. Coordination of a third $\mathrm{BH}_{3} \cdot \mathrm{SMe}_{2}$ molecule occurs via $\mathrm{TS}_{\text {I-J }}(\Delta \mathrm{G}=-41.6$ $\mathrm{kcal} / \mathrm{mol}$ ), requires ca. $29 \mathrm{kcal} / \mathrm{mol}$, due to increased steric crowding. Upon coordination, a B-H bond interacts with the $\mathrm{Al}$ center in complex $\mathbf{J}(\Delta \mathrm{G}=-61.1 \mathrm{kcal} / \mathrm{mol})$. A pathway regenerating complex $\mathbf{B}$ rather than the higher energy complex $\mathbf{A}$ was found from $\mathbf{J}$ involving a second $\mathrm{CO}_{2}$ molecule. In fact, the insertion of $\mathrm{CO}_{2}$ into the $\mathrm{B}-\mathrm{H}$ bond in $\mathbf{J}$ occurs barrierless to form complex $\mathbf{K}$ which is isoelectronic $(\Delta \mathrm{G}=-61.1 \mathrm{kcal} / \mathrm{mol})$. In this complex, a formate $\mathrm{OC}(\mathrm{O}) \mathrm{H}$, a methoxyborane $\mathrm{MeOBH}_{2}$ and $\mathrm{BH}_{3}-$ coordinated $\mathrm{OBH}_{2}$ moieties are bound to $\mathrm{Al}$ which is thus, pentacoordinated. De-coordination of the $\mathrm{MeOBH}_{2}$ moiety is thus quite exergonic to form complex $L(\Delta G=-82.5$ $\mathrm{kcal} / \mathrm{mol}$ ). The $\sigma$-bond metathesis reaction between the $\mathrm{Al}-\mathrm{O}$ and $\mathrm{B}-\mathrm{H}$ bonds occurs by cleaving the $3 \mathrm{c}-2 \mathrm{e}$ interaction between borane moieties through complex $\mathbf{M}$, which results in forming $\mathrm{O}\left(\mathrm{BH}_{2}\right)_{2}$ and regenerating complex $\mathbf{B}$. Finally, as is well known in boron chemistry, three $\mathrm{MeOBH}_{2}$ molecules undergo substituent rearrangements to form $\mathrm{B}(\mathrm{OMe})_{3}$ and $\mathrm{BH}_{3}$, while three $\mathrm{O}\left(\mathrm{BH}_{2}\right)_{2}$ molecules lead to $\mathrm{B}_{2} \mathrm{O}_{3}$ and $\mathrm{BH}_{3}$. In summary, the highest kinetic barrier in the proposed mechanism is $35.5 \mathrm{kcal} / \mathrm{mol}$, related to the third $\mathrm{CH}$ bond formation (complex $\mathbf{T S}_{\mathrm{G}-\mathrm{H}}$ ) between complexes $\mathbf{G}$ and $\mathbf{H}$. The other $\mathrm{CH}$ bond formations are much more facile. The calculation results are thus in accordance with the experimental conditions and observations (formation of formyl complex 4 and acetal complex ${ }_{4} \mathbf{D}$ at room temperature).

Based on the above calculations, the catalytic cycle for the hydroboration of $\mathrm{CO}_{2}$ with $\mathrm{HBpin}$ is pro- 
posed (Scheme 6). Firstly, $\mathrm{CO}_{2}$ inserts into the $\mathrm{Al}-\mathrm{H}$ bond of complex 2 to give to form complex 4. Subsequently, HBpin adds across the $\mathrm{C}=\mathrm{O}$ bond in $\mathbf{4}$ to form IntI. The $\mathrm{Al}-\mathrm{H}$ bond then undergoes $\sigma$-bond metathesis with the $\mathrm{O}$ $\mathrm{C}$ bond to form MeOBpin coordinating with the $\mathrm{Al}$ center. In addition, the resulting $\mathrm{Al}-\mathrm{O}$ bond coordinates with the second HBpin to form IntII. $\mathrm{CO}_{2}$ then displaces MeOBpin and reacts with $\mathrm{HBpin}$ to form a formate moiety bonded to the aluminum in IntIII. The third HBpin undergoes $\sigma$ bond metathesis with the $\mathrm{Al}-\mathrm{O}$ bond in IntIII to form complex 4 and pinBOBpin.

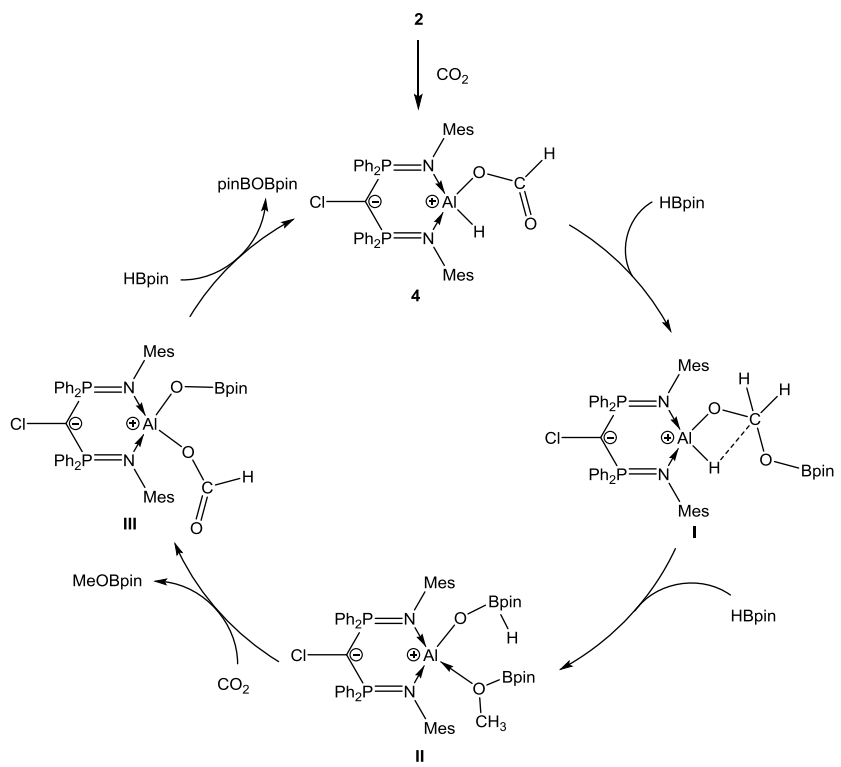

Scheme 6. Catalytic cycle for the hydroboration of $\mathrm{CO}_{2}$ with HBpin

Following the hydroboration of $\mathrm{CO}_{2}$, the catalytic ability of complex 2 towards the hydroboration of carbon$\mathrm{yl}$, alkyne and nitrile derivatives were further examined. Firstly, we verified that there were no reactions between substrates with HBpin in $\mathrm{C}_{6} \mathrm{D}_{6}$ at room temperature or 110 ${ }^{\circ} \mathrm{C}$ without catalyst. On the other hand, catalyzed hydroboration of aromatic aldehyde $\operatorname{ArC}(\mathrm{O}) \mathrm{H}(\mathrm{Ar}=\mathrm{Ph} \mathbf{5 a}$, Table 1) with HBpin as well as its derivatives with electron donating $\left(\mathrm{Ar}=\mathrm{MeC}_{6} \mathrm{H}_{4} \mathbf{5} \mathbf{b} \& \mathbf{5} \mathbf{c}, \mathrm{MeOC}_{6} \mathrm{H}_{4} \mathbf{5} \mathbf{f}\right)$ and withdrawing substituents $\left(\mathrm{MeCO}_{2} \mathrm{C}_{6} \mathrm{H}_{4} \mathbf{5} \mathbf{d}, \mathrm{F}_{3} \mathrm{CC}_{6} \mathrm{H}_{4} \mathbf{5 e}\right)$ were completed in $1 \mathrm{~h}$ using $5 \mathrm{~mol} \%$ of 2 at $60^{\circ} \mathrm{C}$. The corresponding borate esters were obtained in high yield. Secondly, moderate yield was achieved for the hydroboration of non-aromatic aldehydes $\mathbf{5} \mathbf{g}-\mathbf{5 k}$. Thirdly, a higher catalytic loading and temperature were required for the hydroboration of ketones $\mathbf{5 m}-\mathbf{5 p}$ when compared to aldehydes in line with their reduced electrophilic character. Fourthly, 10 mol \% of 2 catalyzed the hydroboration of aromatic nitriles $\operatorname{ArC} \equiv \mathrm{N}$ (Table 2) in high yields. As shown in Table 2, a large scope of electron donating substituent $\left(\mathrm{Ar}=\mathrm{MeOC}_{6} \mathrm{H}_{4} \mathbf{7 b}\right)$, electron withdrawing substituents $\left(\mathrm{Ar}=\mathrm{F}_{3} \mathrm{CC}_{6} \mathrm{H}_{4} \mathbf{7} \mathbf{d}, \mathrm{F}_{2} \mathrm{C}_{6} \mathrm{H}_{3} \mathbf{7 e}\right)$ and sterically hindered substituents $\left(\mathrm{Ar}=\left(\mathrm{CH}_{3}\right)_{3} \mathrm{C}_{6} \mathrm{H}_{2} \mathbf{7 c}\right)$ were hydroborated twice to form the corresponding diboryl amine products $\left[\mathrm{ArCH}_{2} \mathrm{~N}(\mathrm{Bpin})_{2}\right]$. Replacing the aromatic substituents with alkyl groups $(\mathbf{7} \mathbf{f}-\mathbf{7 h})$ resulted in both slower reaction rates and lower product yields. Finally, complex 2 was also able to catalyze the hydroboration of aromatic alkynes $(\mathrm{ArC} \equiv \mathrm{CH}$, 9a - 9d) with electron donating or withdrawing substituents to form the corresponding trans-boryl alkenes trans-[ $\mathrm{Ar}(\mathrm{H}) \mathrm{C}=\mathrm{CH}($ Bpin) $]$. Based on the previous experiments to reduce $\mathrm{CO}_{2}$, it is suggested that the Al- $\mathrm{H}$ bond in complex 2 activates the carbonyl, alkyne or nitrile compounds, which are then reacted with HBpin to form the corresponding hydroborated products, along with the regeneration of complex 2.

Table 1. Catalytic hydroboration of aldehydes and ketones

(18)

${ }^{\mathrm{a}}$ Reaction conditions: Substrate $(0.5 \mathrm{mmol}), 1$ equiv. of HBpin (0.5 mmol), $5 \mathrm{~mol} \%$ of 2 in $\mathrm{C}_{6} \mathrm{D}_{6}(0.5 \mathrm{~mL})$. Yields are determined by ${ }^{1} \mathrm{H}$ NMR spectroscopy on the basis of the consumption of the carbonyl compounds and the identity of the $\mathrm{R}\left(\mathrm{R}^{\prime}\right) \mathrm{C}(\mathrm{H}) \mathrm{OBpin}$ resonances. Isolated yields are reported in parentheses. ${ }^{\mathrm{b}}$ Reaction temperature: $110{ }^{\circ} \mathrm{C}{ }^{\mathrm{C}}$ Catalytic loading of 2: $10 \mathrm{~mol} \%$. All the catalytic trials were repeated in triplicate. 


\section{Conclusion}

In

conclusion, the

bis(iminophosphoranyl)methanide aluminum complex 2 is a versatile catalyst for the hydroboration of carbon dioxide, carbonyl compounds, alkyne and nitrile derivatives with HBpin to form methoxyborane, borate esters, diboryl amines and trans-boryl alkenes, respectively. In particular, complex 2 efficiently reduces $\mathrm{CO}_{2}$ with $\mathrm{BH}_{3} \cdot \mathrm{SMe}_{2}$ to form $\mathrm{B}(\mathrm{OMe})_{3}$. Its activity is higher than that of known base-metal catalysts used for such reaction. We have observed that the additions to form the formate $\mathrm{AlOCHO}$ and the acetal $\mathrm{AlOCH}_{2} \mathrm{OAl}$ derivatives are facile. DFT calculations rationalized that further reduction to the methanol derivative is rather demanding. In light of its transition-metal-like reactivity, we believe that complex 2 or its analogues, will find uses in other catalytic applications. Such endeavors are currently pursued in our laboratories and results will be reported in due course.

$8 d$

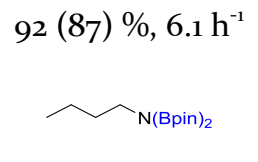

$8 \mathrm{~g}$

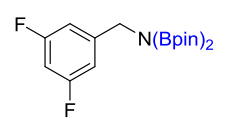

$8 \mathrm{e}$ $91(89) \%, 6.1 \mathrm{~h}^{-1}$

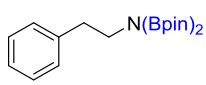

$8 h$

$38 \%, 2.5 \mathrm{~h}^{-1} \quad 23 \%, 1.5 \mathrm{~h}^{-1}$

a Reaction conditions: Nitrile compounds (0.2 mmol), 2 equiv. of HBpin ( $0.4 \mathrm{mmol}), \mathrm{C}_{6} \mathrm{D}_{6}(0.5 \mathrm{~mL})$. Catalyst loading is relative to the nitrile compounds. Yields are determined by ${ }^{1} \mathrm{H}$ NMR spectroscopy on the basis of the consumption of the nitrile compounds and the identity of the $\mathrm{RCH}_{2} \mathrm{~N}$ (Bpin) $)_{2}$ resonances. Isolated yields are reported in parentheses. All the catalytic trials were repeated in triplicate.

Table 3. Catalytic hydroboration of alkynes

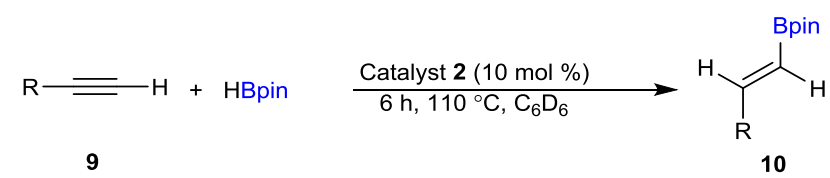

10a

${ }^{a}$ Reaction conditions: Alkyne compounds (0.5 mmol), 1 equiv. of HBpin (o.5 mmol), $\mathrm{C}_{6} \mathrm{D}_{6}(0.5 \mathrm{~mL})$. Catalyst loading is relative to the alkyne compounds. Yields are determined by ${ }^{1} \mathrm{H}$ NMR spectroscopy on the basis of the consumption of the alkyne compounds and the identity of the trans- $\mathrm{RCH}=\mathrm{CBpin}$ resonances. Isolated yields are reported in parentheses. All the catalytic trials were repeated in triplicate.

\section{Experimental Section}

General procedures. All manipulations were carried out under an inert atmosphere of argon gas by standard Schlenk techniques. Compound $\mathbf{1}$ was prepared according to the literature procedure. ${ }^{22}$ Toluene was dried over $\mathrm{Na} / \mathrm{K}$ alloy and distilled prior to use. $\mathrm{C}_{6} \mathrm{D}_{6}$ was dried over $\mathrm{K}$ metal and distilled prior to use. $\mathrm{CDCl}_{3}$ was dried over $\mathrm{CaH}_{2}$ and distilled prior to use. Chemicals were purchased from Sigma-Aldrich. They were degassed when received and then stored in a glove box. They used directly without further purification. The ${ }^{1} \mathrm{H},{ }^{11} \mathrm{~B}\left\{{ }^{1} \mathrm{H}\right\},{ }^{13} \mathrm{C}\left\{{ }^{1} \mathrm{H}\right\}$ and ${ }^{31} \mathrm{P}\left\{{ }^{1} \mathrm{H}\right\}$ NMR spectra were recorded on a JEOL ECA 400 spectrometer. The NMR spectra were recorded in $\mathrm{C}_{6} \mathrm{D}_{6}$ and the chemical shifts are relative to $\mathrm{SiMe}_{4}$ for ${ }^{1} \mathrm{H},{ }^{13} \mathrm{C}$ and ${ }^{29} \mathrm{Si}$; $\mathrm{BF}_{3} \mathrm{Et}_{2} \mathrm{O}$ for ${ }^{11} \mathrm{~B}, \mathrm{H}_{3} \mathrm{PO}_{4}$ for ${ }^{31} \mathrm{P}$ respectively. Electrospray ionization (ESI) mass spectra were obtained at the Mass Spectrometry Laboratory at the Division of Chemistry and Biological Chemistry, Nanyang Technological University.

Synthesis of 2: $\mathrm{AlH}_{3} \cdot \mathrm{EtNMe}_{2}(2.0 \mathrm{mmol})$ was added dropwise to a solution of $\mathbf{1}(1.0 \mathrm{mmol})$ in toluene at $-78{ }^{\circ} \mathrm{C}$ in a Schlenk flask. The reaction mixture was raised to room temperature and a white suspension was observed. The mixture was stirred for 1 hour and was subsequently dried under vacuum to remove excess $\mathrm{AlH}_{3} \cdot \mathrm{EtNMe}_{2}$. The residue was extracted with $10 \mathrm{ml}$ of toluene to yield a white precipitate. Yield: $0.65 \mathrm{~g}, 0.92 \mathrm{mmol}$ (91\%, based on 1). Colorless crystals were grown from concentrated toluene solution of 2. ${ }^{1} \mathrm{H}$ NMR (395.9 MHz, $\left.\mathrm{C}_{6} \mathrm{D}_{6}, \mathrm{ppm}\right): \delta 8.02(\mathrm{~m}$, $8 \mathrm{H}, m-\mathrm{Ph}-H), 7.04(\mathrm{~m}, 12 \mathrm{H}, o, p-\mathrm{Ph}-H), 6.55(\mathrm{~s}, 4 \mathrm{H}, m-$ Mes- $H$ ), $5.00\left(\mathrm{br}, 2 \mathrm{H}, \mathrm{Al}_{2}\right), 2.23\left(\mathrm{~s}, 12 \mathrm{H}, \mathrm{o}-\mathrm{CH}_{3}\right), 2.01(\mathrm{~s}$, $\left.\left.6 \mathrm{H}, p-\mathrm{CH}_{3}\right) .{ }^{13} \mathrm{C}^{1}{ }^{1} \mathrm{H}\right\}$ NMR $\left(99.5 \mathrm{MHz}, \mathrm{C}_{6} \mathrm{D}_{6}, \mathrm{ppm}\right): \delta 138.30$ (t, Ph $m-C$ ), 137.81 (s, Mes $m-C$ ), 134.26 (t, Ph o-C), 133.96 (s, Mes o-C), $131.14(\mathrm{~s}, \mathrm{Ph} p-C), 130.75\left(\mathrm{~d}, J_{\mathrm{P}-\mathrm{C}}=102.95 \mathrm{~Hz}\right.$, $\mathrm{Ph}$ ipso-C), 130.6o (t, $\left.\mathrm{P}_{2} C\right)$, 129.71 (s, Mes $\left.p-C\right), 127.29\left(\mathrm{t}, J_{\mathrm{P}-}\right.$ $\mathrm{c}=5.72 \mathrm{~Hz}$, Mes ipso- $\mathrm{C}), 20.83\left(\mathrm{~s}, \mathrm{Mes} o-\mathrm{CH}_{3}\right), 20.42(\mathrm{~s}$, 
Mes $\left.p-\mathrm{CH}_{3}\right) .{ }^{31} \mathrm{P}\left\{{ }^{1} \mathrm{H}\right\}$ NMR (121.5 MHz, $\left.\mathrm{C}_{6} \mathrm{D}_{6}\right) \delta 38.98$ (s). HRMS (ESI): $m / z$ calcd for $\mathrm{C}_{43} \mathrm{H}_{45} \mathrm{~N}_{2} \mathrm{AlP}_{2} \mathrm{Cl}$ : $713.2562[(\mathrm{M}+$ $\mathrm{H})]^{+}$; found: 713.2573 .

Synthesis of 4: Complex 2 (1.43 g, $2.0 \mathrm{mmol})$ was dissolved in $40 \mathrm{ml}$ of toluene in a Schlenk flask. The reaction mixture was freeze-pump-thaw degassed thrice. $\mathrm{CO}_{2}$ gas $(1$ bar) was streamed into the flask using a Schlenk line along with vigorous stirring. After 15 minutes, the reaction mixture was dried under vacuum to yield a white precipitate. Yield: $1.51 \mathrm{~g}$ (100 \%). ${ }^{1} \mathrm{H}$ NMR (395.9 MHz, $\left.\mathrm{C}_{6} \mathrm{D}_{6}, \mathrm{ppm}\right): \delta 8.52\left(\mathrm{~s},{ }_{1} \mathrm{H}, \mathrm{OC}(=\mathrm{O}) H\right), 8.12\left(\mathrm{~m},{ }_{4} \mathrm{H}, \mathrm{m}-\mathrm{Ph}-\right.$ $H), 7.88(\mathrm{~m}, 4 \mathrm{H}, m-\mathrm{Ph}-H), 7.10(\mathrm{~m}, 4 \mathrm{H}, p-\mathrm{Ph}-H), 7.02(\mathrm{~m}$, $8 \mathrm{H}, o-\mathrm{Ph}-H), 6.57$ (s, $2 \mathrm{H}, m$-Mes- $H), 6.50$ (s, 2H, m-Mes$H), 2.26\left(\mathrm{~s}, 6 \mathrm{H}, \mathrm{o}-\mathrm{CH}_{3}\right), 2.12\left(\mathrm{~s}, 6 \mathrm{H}, \mathrm{o}-\mathrm{CH}_{3}\right), 1.99(\mathrm{~s}, 6 \mathrm{H}, p-$ $\left.\mathrm{CH}_{3}\right) .{ }^{13} \mathrm{C}\left\{{ }^{1} \mathrm{H}\right\}$ NMR $\left(99.5 \mathrm{MHz}, \mathrm{C}_{6} \mathrm{D}_{6}, \mathrm{ppm}\right): \delta 161.6(\mathrm{~s}$, $C(\mathrm{O}) \mathrm{H}), 138.1\left(\mathrm{~d}, J_{\mathrm{P}-\mathrm{C}}=53.2 \mathrm{~Hz}\right.$, Mes, ipso-C), $136.4(\mathrm{~s}, \mathrm{Mes}$ o-C), 134.8 (s, Ph m-C), 134.3 (s, Ph o-C), 131.5 (s, Mes p-C), 131.3 (s, Ph m-C), 129.8 (d, $J_{\mathrm{P}-\mathrm{C}}=53.2 \mathrm{~Hz}, \mathrm{Ph}$ ipso-C), 124.4 (s, Ph p-C), 20.8 (s, Mes $p-\mathrm{CH}_{3}$ ), 20.6 (s, Mes $p-\mathrm{CH}_{3}$ ), not observable (PCP). ${ }^{31} \mathrm{P}\left\{{ }^{1} \mathrm{H}\right\}$ NMR (121.5 MHz, $\left.\mathrm{C}_{6} \mathrm{D}_{6}, \mathrm{ppm}\right): \delta$ 40.55 (s). HRMS (ESI): $\mathrm{m} / \mathrm{z}$ calcd for $\mathrm{C}_{44} \mathrm{H}_{45} \mathrm{~N}_{2} \mathrm{O}_{2} \mathrm{AlP}_{2} \mathrm{Cl}$ : 757.246o $[(\mathrm{M}+\mathrm{H})]^{+}$; found: 757.2467 .

Synthesis of 4-D: Complex 2 (1.43 g, $2.0 \mathrm{mmol})$ was dissolved in $40 \mathrm{ml}$ of toluene in a Schlenk flask. The reaction mixture was freeze-pump-thaw degassed thrice. $\mathrm{CO}_{2}$ gas (1 bar) was streamed into the flask using a Schlenk line along with vigorous stirring. Upon stirring for 16 hours, white precipitates were observed in the flask. The reaction mixture was dried under vacuum and extracted with DCM (1o ml) and hexane $(1 \mathrm{ml})$ mixture. The resulting filtrate was left to stand at $0^{\circ} \mathrm{C}$ to yield colourless crystals of 4-D. Yield: o.o8g (5.3\%). ${ }^{1} \mathrm{H}$ NMR (395.9 MHz, $\mathrm{C}_{6} \mathrm{D}_{6}$, ppm): $\delta 8.24\left(\mathrm{~s}, 4 \mathrm{H}, \mathrm{OCH}_{2} \mathrm{O}\right), 8.02(\mathrm{~m}, 16 \mathrm{H}, m-\mathrm{Ph}-H), 7.08$ (m, $24 \mathrm{H}, o, p-\mathrm{Ph}-H), 6.52$ (s, 8H, m-Mes- $H), 2.13(\mathrm{~s}, 24 \mathrm{H}, o-$ $\left.\mathrm{CH}_{3}\right), 1.98\left(\mathrm{~s}, 12 \mathrm{H}, p-\mathrm{CH}_{3}\right) .{ }^{13} \mathrm{C}\left\{{ }^{1} \mathrm{H}\right\}$ NMR $\left(99.5 \mathrm{MHz}, \mathrm{C}_{6} \mathrm{D}_{6}\right.$, ppm): $\delta 161.3$ (s, O-C $\mathrm{H}_{2}-\mathrm{O}$ ), 138.1 (s, Mes o-C), 135.5 (s, Ph $m-\mathrm{C}$ ), 135.1 (s, Ph o-C), 134.4 (t, Mes, ipso-C),131.7 (s, Mes $p-\mathrm{C}), 129.8$ (s, Ph $m-\mathrm{C}$ ), overlapped with solvent ( $\mathrm{Ph}$ ipsoC), 124.4 (s, Ph $p-\mathrm{C}$ ), 20.5 (s, Mes $p-\mathrm{CH}_{3}$ ), 20.3 (s, Mes o$\mathrm{CH}_{3}$ ), not observable (PCP). ${ }^{31} \mathrm{P}\left\{{ }^{1} \mathrm{H}\right\}$ NMR $\left(121.5 \mathrm{MHz}, \mathrm{C}_{6} \mathrm{D}_{6}\right.$, ppm): $\delta \quad 40.55$ (s). HRMS (ESI): $\mathrm{m} / \mathrm{z}$ calcd for $\mathrm{C}_{88} \mathrm{H}_{89} \mathrm{~N}_{4} \mathrm{O}_{4} \mathrm{Al}_{2} \mathrm{P}_{4} \mathrm{Cl}_{2}: 1513.4842[(\mathrm{M}+\mathrm{H})]^{+}$; found: 1513.4854.

Complex 2 Catalyzed Hydroboration with HBPin: In a JYoung NMR tube, complex $2(0.035 \mathrm{~g}, 0.05 \mathrm{mmol})$ and 1,3,5-tri-tert-butylbenzene (o.0245 g, o.10 mmol, internal standard) were dissolved in toluene $(0.5 \mathrm{ml})$. HBpin (o.064g, $0.5 \mathrm{mmol}$ ) was then added into the tube. The reaction mixture was freeze-pump-thaw degassed thrice. $\mathrm{CO}_{2}$ gas (1 bar) was streamed into the tube using a Schlenk line. The tube was subsequently heated under $110^{\circ} \mathrm{C}$ for 48 hrs. Yield was calculated based on total number of protons converted into methoxy product based on the integral of internal standard. Yield $=78.4 \%$.
Complex 2 Catalyzed Hydroboration with $\mathrm{BH}_{3} \cdot \mathrm{SMe}_{2}$ : In a J-Young NMR tube, complex 2 (0.0035 g, $0.005 \mathrm{mmol})$ were dissolved in toluene $(0.5 \mathrm{ml}) \cdot \mathrm{BH}_{3} \cdot \mathrm{SMe}_{2}(0.038 \mathrm{~g}, 0.5$ mmol) was then added into the tube. The reaction mixture was freeze-pump-thaw degassed thrice. $\mathrm{CO}_{2}$ gas $(1$ bar) was streamed into the tube using a Schlenk line. The tube was subsequently heated under $110^{\circ} \mathrm{C}$ for $1 \mathrm{hr} . \mathrm{CH}_{3}$ protons of $\mathrm{SMe}_{2}$ were used as the internal standard for calculating yield. Yield was calculated based on total number of protons converted into methoxy product. Yield $=97.6 \%$.

Complex 2 Catalyzed Hydroboration with HBCat: In a JYoung NMR tube, complex 2 (0.035 g, $0.05 \mathrm{mmol})$ and 1,3,5-tri-tert-butylbenzene (0.0182 g, $0.074 \mathrm{mmol}$, internal standard) were dissolved in toluene $(0.5 \mathrm{ml})$. HBCat ( $0.064 \mathrm{~g}, 0.5 \mathrm{mmol}$ ) was then added into the tube. The reaction mixture was freeze-pump-thaw degassed thrice. $\mathrm{CO}_{2}$ gas (1 bar) was streamed into the tube using a Schlenk line. The tube was subsequently heated under $110^{\circ} \mathrm{C}$ for 24 hrs. Yield was calculated based on total number of protons converted into methoxy product based on the integral of internal standard. Yield $=\mathbf{2 8 . 8} \%$.

General procedures for the complex $\mathbf{2}$ catalyzed hydroboration of carbonyl compounds, nitriles and alkynes: Hydroboration (Tables 1-3) were performed in J-Young NMR tube under Ar gas. Complex 2 was dissolved into $0.5 \mathrm{ml}$ of $\mathrm{C}_{6} \mathrm{D}_{6}$. HBPin was then added into the solution and followed by addition of the respective substrates. The tube was subsequently heated in an oil bath in respective temperatures. The conversion of the substrates were obtained based on total number of protons converted into their hydroborated products. The products were isolated by drying the reaction mixture under vacuum, followed by extraction with $\mathrm{n}$-hexane. The resulting solution were dried under vacuum and characterized by NMR spectroscopy. Isolated yields of selected products were subsequently obtained by weight.

\section{ASSOCIATED CONTENT}

Supporting Information. The Supporting Information is available free of charge on the ACS Publications website.

Experimental procedures (PDF), theoretical studies (XYZ) $\mathrm{X}$-ray crystallographic data (CIF)

\section{AUTHOR INFORMATION}

\section{Corresponding Author}

${ }^{*}$ C.-W. So: CWSo@ntu.edu.sg

*N. Mézailles: mezailles@chimie.ups-tlse.fr.

\section{Author Contributions}

The manuscript was written through contributions of all authors. All authors have given approval to the final version of the manuscript.

\section{ACKNOWLEDGMENT}


This work is supported by the National Research Foundation Singapore, NRF-ANR (NRF2018-NRF-ANRo26 Si-POP) and Ministry of Education Singapore, AcRF Tier 2 (MOE2019-T22-129) (C.-W. So). We thank CalMip (CNRS, Toulouse, France) for access to calculation facilities

\section{REFERENCES}

(1) (a) Harder, S. Early Main Group Metal Catalysis: Concepts and Reactions; Wiley-VCH: Weinheim, Germany, 2019. (b) Power, P. P. Main-group Elements as Transition metals. Nature 2010, 463, 171-177. (c) Weetman, C.; Inoue, S. The Road Travelled: After Main-Group Elements as Transition Metals. ChemCatChem 2018, 10, 4213-4228 and references therein.

(2) (a) Meerwein, H.; Schmidt, R. Ein neues Verfahren zur Reduktion von Aldehyden und Ketonen. Justus Liebigs Ann. Chem. 1925, 444, 221-238. (b) Verley, A. Exchange of Functional Groups between Two Molecules. Exchange of Alcohol and Aldehyde Groups. Bull. Soc. Chim. Fr. 1925, 37, 537-542. (c) Ponndorf, W. Der reversible Austausch der Oxydationsstufen zwischen Aldehyden oder Ketonen einerseits und primären oder sekundären Alkoholen anderseits. Angew. Chem. 1926, 39, 138 - 143.

(3) Friedel, C.; Crafts, J. M. Sur une nouvelle méthode générale de synthèse d'hydrocarbures, d'acétones, etc.. Compt. Rend. 1877, 84, 1392-1450.

(4) Wei, Y.; Wang, S.; Zhou, S. Aluminum Alkyl Complexes: Synthesis, Structure, and Application in ROP of Cyclic Esters. Dalton Trans. 2016, 45, 4471-4485.

(5) (a) Nikonov, G. I. New Tricks for an Old Dog: Aluminum Compounds as Catalysts in Reduction Chemistry. ACS Catalysis 2017, 7, 7257-7266. (b) Less, R. J.; Simmonds, H. R.; Wright, D. S. Reactivity and Catalytic Activity of tertButoxy-aluminum Hydride Reagents. Dalton Trans. 2014, 43, 5785-5792. (c) Jakhar, V. K.; Barman, M. K.; Nembenna, S. Aluminum Monohydride Catalyzed Selective Hydroboration of Carbonyl Compounds. Org. Lett. 2016, 18, 4710-4713. (d) Zhang, G.; Wu, J.; Zeng, H.; Neary, M. C.; Devany, M.; Zheng, S.; Dub, P. A. Dearomatization and Functionalization of Terpyridine Ligands Leading to Unprecedented Zwitterionic Meisenheimer Aluminum Complexes and Their Use in Catalytic Hydroboration. ACS Catalysis 2019, 9, 874-884. (e) Mukherjee, D.; Osseili, H.; Truong, K.-N.; Spaniol, T. P.; Okuda, J. Ring-opening of Cyclic Ethers by Aluminum Hydridotriphenylborate. Chem. Commun. 2017, 53, 3493-3496. (f) Franz, D.; Sirtl, L.; Poethig, A.; Inoue, S. Aluminum Hydrides Stabilized by N-Heterocyclic Imines as Catalysts for Hydroborations with Pinacolborane. Z. Anorg. Allg. Chem. 2016, 642, 1245-1250. (g) Prashanth, B.; Bhandari, M.; Ravi, S.; Shamasundar, K. R.; Singh, S. Electronically Unsaturated Three-Coordinate Aluminum Hydride and Organoaluminum Cations. Chem. - Eur. J. 2018, 24, 4794-4799.

(6) Myers, T. W.; Berben, L. A. Aluminum-Ligand Cooperative $\mathrm{N}-\mathrm{H}$ Bond Activation and an Example of Dehydrogenative Coupling. J. Am. Chem. Soc. 2013, 135, 9988-9990.

(7) Myers, T. W.; Berben, L. A. Aluminum-Ligand Cooperation Promotes Selective Dehydrogenation of Formic Acid to $\mathrm{H}_{2}$ and $\mathrm{CO}_{2}$. Chem. Sci. 2014, 5, 2771-2777.

(8) Thompson, E. J.; Berben, L. A. Electrocatalytic Hydrogen Production by an Aluminum(III) Complex: Ligand-Based Proton and Electron Transfer. Angew. Chem., Int. Ed. 2015, $54,11642-11646$.

(9) Yang, Z.; Zhong, M.; Ma, X.; De, S.; Anusha, C.; Parameswaran, P.; Roesky, H. W. An Aluminum Hydride That Functions like a Transition-Metal Catalyst. Angew. Chem., Int. Ed. 2015, 54, 10225-10229.
(10) Yang, Z.; Zhong, M.; Ma, X.; Nijesh, K.; De, S.; Parameswaran, P.; Roesky, H. W. An Aluminum Dihydride Working as a Catalyst in Hydroboration and Dehydrocoupling. J. Am. Chem. Soc. 2016, 138, 2548-2551.

(11) Bismuto, A.; Thomas, S. P.; Cowley, M. J. Aluminum Hydride Catalyzed Hydroboration of Alkynes. Angew Chem Int Ed Engl 2016, 55, 15356-15359.

(12) Bismuto, A.; Cowley, M. J.; Thomas, S. P. AluminumCatalyzed Hydroboration of Alkenes. ACS Catalysis 2018, 8, 2001-2005.

(13) Elsen, H.; Färber, C.; Ballmann, G.; Harder, S. LiAlH 4 : From Stoichiometric Reduction to Imine Hydrogenation Catalysis. Angew. Chem., Int. Ed. 2018, 57, 7156-7160.

(14) (a) Pollard, V. A.; Fuentes, M. A.; Kennedy, A. R.; McLellan, R.; Mulvey, R. E. Comparing Neutral (Monometallic) and Anionic (Bimetallic) Aluminum Complexes in Hydroboration Catalysis: Influences of Lithium Cooperation and Ligand Set. Angew. Chem., Int. Ed. 2018, 57, 10651-10655. (b) Pollard, V. A.; Young, A.; McLellan, R.; Kennedy, A. R.; Tuttle, T.; Mulvey, R. E. Lithium-Aluminate-Catalyzed Hydrophosphination Applications. Angew. Chem., Int. Ed. 2019, 58, 12291-12296.

(15) Jakobsson, K.; Chu, T.; Nikonov, G. I. Hydrosilylation of Olefins Catalyzed by Well-Defined Cationic Aluminum Complexes: Lewis Acid versus Insertion Mechanisms. ACS Catalysis 2016, 6, 7350-7356.

(16) Lebedev, Y.; Polishchuk, I.; Maity, B.; Dinis Veloso Guerreiro, M.; Cavallo, L.; Rueping, M. Asymmetric Hydroboration of Heteroaryl Ketones by Aluminum Catalysis. J. Am. Chem. Soc. 2019, 141, 19415-19423.

(17) Strongly Lewis acidic aluminum complexes such as $\mathrm{AlBr}_{3}$, $\mathrm{Al}\left(\mathrm{C}_{6} \mathrm{~F}_{5}\right)_{3},\left[\mathrm{Et}_{2} \mathrm{Al}\right]\left[\mathrm{CH}_{6} \mathrm{~B}_{11} \mathrm{I}_{6}\right]$ have been used in catalytic $\mathrm{CO}_{2}$ reduction processes: (a) Ménard, G.; Stephan, D. W. Room Temperature Reduction of $\mathrm{CO}_{2}$ to Methanol by Al-Based Frustrated Lewis Pairs and Ammonia Borane. J. Am. Chem. Soc. 2010, 132, 1796-1797. (b) Chen, J.; Falivene, L.; Caporaso, L.; Cavallo, L.; Chen, E. Y. X. Selective Reduction of $\mathrm{CO}_{2}$ to $\mathrm{CH}_{4}$ by Tandem Hydrosilylation with Mixed $\mathrm{Al} / \mathrm{B}$ Catalysts. J. Am. Chem. Soc. 2016, 138, 5321-5333.

(18) Caise, A.; Jones, D.; Kolychev, E. L.; Hicks, J.; Goicoechea, J. M.; Aldridge, S. On the Viability of Catalytic Turnover via Al-O/B-H Metathesis: The Reactivity of $\beta$-Diketiminate Aluminum Hydrides towards $\mathrm{CO}_{2}$ and Boranes. Chem. - Eur. J. 2018, 24, 13624-13635.

(19) Franz, D.; Jandl, C.; Stark, C.; Inoue, S. Catalytic $\mathrm{CO}_{2}$ Reduction with Boron- and Aluminum Hydrides. ChemCatChem 2019, 11, 5275-5281.

(2o) (a) Panda, T. K.; Roesky, P. W. Main-group and Transitionmetal Complexes of Bis(phosphinimino)methanides. Chem Soc Rev 2009, 38, 2782-2804. (b) Fustier-Boutignon, M.; Nebra, N.; Mézailles, N. Geminal Dianions Stabilized by Main Group Elements. Chem. Rev. 2019, 119, 8555-8700.

(21) Lafage, M.; Pujol, A.; Saffon-Merceron, N.; Mézailles, N. $\mathrm{BH}_{3}$ Activation by Phosphorus-Stabilized Geminal Dianions: Synthesis of Ambiphilic Organoborane, DFT Studies, and Catalytic $\mathrm{CO}_{2}$ Reduction into Methanol Derivatives. ACS Catalysis 2016, 6, 3030-3035.

(22) Ho, S. Y. F.; So, C.-W.; Saffon-Merceron, N.; Mezailles, N. Formation of a Zwitterionic Boronium Species from the Reaction of a Stable Carbenoid with Borane: $\mathrm{CO}_{2}$ Reduction. Chem. Commun. 2015, 51, 2107-2110.

(23) (a) Abdalla, J. A. B.; Riddlestone, I. M.; Tirfoin, R.; Aldridge, S. Cooperative Bond Activation and Catalytic Reduction of Carbon Dioxide at a Group 13 Metal Center. Angew. Chem., Int. Ed. 2015, 54, 5098-5102. (b) Anker, M. D.; Arrowsmith, M.; Bellham, P.; Hill, M. S.; Kociok-Koehn, G.; Liptrot, D. J.; Mahon, M. F.; Weetman, C. Selective Reduction of $\mathrm{CO}_{2}$ to a 
Methanol Equivalent by $\mathrm{B}\left(\mathrm{C}_{6} \mathrm{~F}_{5}\right)_{3}$-Activated Alkaline Earth Catalysis. Chem. Sci. 2014, 5, 2826-2830. (c) Chong, C. C.; Kinjo, R. Catalytic Hydroboration of Carbonyl Derivatives, Imines, and Carbon Dioxide. ACS Catal. 2015, 5, 3238-3259. (d) Hadlington, T. J.; Kefalidis, C. E.; Maron, L.; Jones, C. Efficient Reduction of Carbon Dioxide to Methanol Equivalents Catalyzed by Two-Coordinate Amido-Germanium(II) and -Tin(II) Hydride Complexes. ACS Catal. 2017, 7, 18531859.

(24) Fujiwara, K.; Yasuda, S.; Mizuta, T. Reduction of $\mathrm{CO}_{2}$ to Trimethoxyboroxine with $\mathrm{BH}_{3}$ in THF. Organometallics 2014, 33, 6692-6695.

(25) (a) Courtemanche, M.-A.; Légaré, M.-A.; Maron, L.; Fontaine, F.-G. A Highly Active Phosphine-Borane Organocatalyst for the Reduction of $\mathrm{CO}_{2}$ to Methanol Using Hydroboranes. J. Am. Chem. Soc. 2013, 135, 9326-9329. (b) Courtemanche, M.-A.; Légaré, M.-A.; Maron, L.; Fontaine, F.-G. Reducing $\mathrm{CO}_{2}$ to Methanol Using Frustrated Lewis Pairs: On the Mechanism of Phosphine-Borane-Mediated Hydroboration of $\mathrm{CO}_{2}$. J. Am. Chem. Soc. 2014, 136, 1070810717. (c) Declercq, R.; Bouhadir, G.; Bourissou, D.; Légaré, M.-A.; Courtemanche, M.-A.; Nahi, K. S.; Bouchard, N.; Fontaine, F.-G.; Maron, L. Hydroboration of Carbon Dioxide Using Ambiphilic Phosphine-Borane Catalysts: On the Role of the Formaldehyde Adduct. ACS Catalysis 2015, 5, 2513-2520.

(26) Wang, T.; Stephan, D. W. Carbene-9-BBN Ring Expansions as a Route to Intramolecular Frustrated Lewis Pairs for $\mathrm{CO}_{2}$ Reduction. Chem. - Eur. J. 2014, 20, 3036-3039.
(27) Leong, B.-X.; Lee, J.; Li, Y.; Yang, M.-C.; Siu, C.-K.; Su, M.D.; So, C.-W. A Versatile NHC-Parent Silyliumylidene Cation for Catalytic Chemo- and Regioselective Hydroboration. J. Am. Chem. Soc. 2019, 141, 17629-17636.

(28) Tan, G.; Wang, W.; Blom, B.; Driess, M. Mechanistic Studies of $\mathrm{CO}_{2}$ Reduction to Methanol Mediated by an NHeterocyclic Germylene Hydride. Dalton Trans. 2014, 43, 6006-6o11.

(29) In Thomas, S. P. et al. Org. Let. 2020, 22, 4107-4112, $\mathrm{BH}_{3}$ was found as hidden catalyst. To verify whether $\mathrm{BH}_{3}$ could be formed in the catalysis (Scheme 2), HBpin reacted with 10 mol \% of complex 2 in $\mathrm{C}_{6} \mathrm{D}_{6}$ at $110^{\circ} \mathrm{C}$ for $48 \mathrm{~h}$ and no reduction of HBpin was observed. To conform that there was no $\mathrm{BH}_{3}$, TMEDA was then added to the mixture at room temperature and no TMEDA- $\left(\mathrm{BH}_{3}\right)_{\mathrm{n}}(\mathrm{n}=1,2)$ complexes were formed. The results suggest that no $\mathrm{BH}_{3}$ or adducts thereof, or $\mathrm{BH}_{4}^{-}$or other borate species were formed in the catalysis. Complex $\mathbf{2}$ is the only active catalyst in the hydroboration of $\mathrm{CO}_{2}$. Even if $\mathrm{BH}_{3}$ was formed in catalysis, it could be reacted with compound $\mathbf{2}$ in the hydroboration. To support this, 10 mol \% of complex 2, $10 \mathrm{~mol}^{\%}$ of $\mathrm{BH}_{3} \cdot \mathrm{SMe}_{2}, \mathrm{HBpin}$ and $4^{-}$ (trifluoromethyl)benzaldehyde $\left[\mathrm{OC}(\mathrm{H})\left(4-\mathrm{CF}_{3}-\mathrm{C}_{6} \mathrm{H}_{4}\right)\right] \quad$ (5e) were reacted in $\mathrm{C}_{6} \mathrm{D}_{6}$ at $60{ }^{\circ} \mathrm{C}$, a mixture of $\mathbf{6 e}$ and borate ester $\left[\mathrm{B}\left\{\mathrm{OCH} 2\left(4-\mathrm{CF}_{3}-\mathrm{C}_{6} \mathrm{H}_{4}\right)\right\}_{3}\right]\left({ }^{11} \mathrm{~B}=17.52 \mathrm{ppm}\right)$ was formed 
SYNOPSIS TOC. The bis(phosphoranyl)methanido aluminum hydride catalyzed the reduction of $\mathrm{CO}_{2}$ with $\mathrm{BH}_{3} \cdot \mathrm{SMe}_{2}$ to afford trimethyl borate $\left[\mathrm{B}(\mathrm{OMe})_{3}\right]$ and $\mathrm{B}_{2} \mathrm{O}_{3}$.

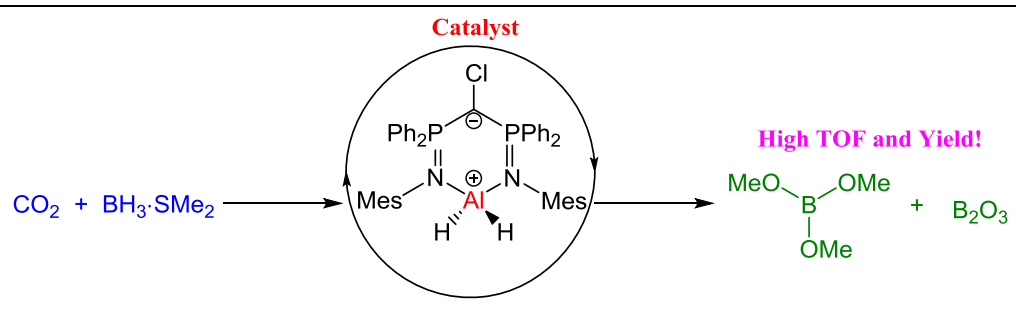

